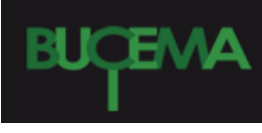

Bulletin du centre d'études médiévales d'Auxerre | BUCEMA

Hors-série $n^{\circ} 7 \mid 2013$

Les nouveaux horizons de l'ecclésiologie : du discours clérical à la science du social

\title{
L'Église comme « économie » du divin
}

\section{(2) OpenEdition}

Journals

Édition électronique

URL : https://journals.openedition.org/cem/12892

DOI : $10.4000 /$ cem. 12892

ISSN : 1954-3093

Éditeur

Centre d'études médiévales Saint-Germain d'Auxerre

Référence électronique

"L'Église comme « économie » du divin », Bulletin du centre d'études médiévales d'Auxerre | BUCEMA [En ligne], Hors-série $n^{\circ} 7$ | 2013, mis en ligne le 29 juillet 2013, consulté le 03 mars 2023. URL : http:// journals.openedition.org/cem/12892 ; DOI : https://doi.org/10.4000/cem.12892

Ce document a été généré automatiquement le 3 mars 2023.

\section{(9) $\odot \Theta(\odot)$}

Creative Commons - Attribution - Pas d'Utilisation Commerciale - Partage dans les Mêmes Conditions 4.0 International - CC BY-NC-SA 4.0

https://creativecommons.org/licenses/by-nc-sa/4.0/ 

